\title{
The Technology for Forming Professional Reflection in Future Social Work Educators in a Higher Educational Institution
}

\author{
Chernukha Nadezhda \\ ORCID https://orcid.org/0000-0003-2184-7406/print. \\ Doctor of Pedagogical sciences, Professor \\ Vasylieva-Khalatnykova Maryna \\ ORCID https://orcid.org/0000-0002-8488-4602/print. \\ Lecturer \\ Tokaruk Lyudmyla \\ ORCID https://orcid.org/0000-0002-7330-406X/print. \\ Ph.D., Associate Professor \\ Department of social rehabilitation and social pedagogy \\ Taras Shevchenko National University (Kyiv, Ukraine)
}

\begin{abstract}
The article analyzes the technology for forming professional reflection in future social work educators in a higher education institution. Given technology is described as scientific and theoretical basis for the optimal implementation of the tasks of professional training. This technology is considered as a set of regular, functionally related components which presents an integral system. Selected components in technology are divided into some blocks (goal-oriented, functional, informative, organizational, productive). This components provide an opportunity to represent more clearly the purposeful process of forming professional reflection in future social work educators in the higher education institution. They highlighted how social work educators' future work in agencies help them to operationalize social work values and ethics, develop an awareness of themselves as social workers, and enhanced their confidence.
\end{abstract}

Key words: technology, professional reflection, social teacher, institution of higher education, pedagogical conditions.

Актуальність. Для успішної реалізації завдань у системі професійної освіти доцільно мати чітку науково-теоретичну основу для обгрунтування та розробки технології формування професійної рефлексії майбутніх соціальних педагогів у закладі вищої школи.

Сучасні зміни в українському соціумі обумовлюють необхідність створення ефективної системи підготовки фахівців для соціальної та соціальнопедагогічної роботи. Сьогодення, виклики часу потребують фахівця, здатного організовувати, сприяти створенню соціальних умов для реалізації цілей різних категорій клієнтів у професійній і життєвій самореалізації $[1 ; 2 ; 7 ; 9 ; 10 ; 11 ; 12]$. 
Метою статті є розкриття особливостей впровадження технології формування професійної рефлексії майбутніх соціальних педагогів у закладі вищої школи.

Технологія формування професійної рефлексії майбутніх соціальних педагогів у закладі вищої школи інтегрує критичне, альтернативне мислення майбутніх соціальних педагогів, їх дослідницьку, професійну позицію, що спирається на фундамент концептуальних та соціально-значущих критеріїв аналізу та оцінки професійної діяльності.

Варто зазначити, що професійна діяльність майбутніх соціальних педагогів нерозривно пов'язана зі спілкуванням. Завдяки йому майбутні соціальні педагоги вчаться самовизначенню, виробленню професійної позиції, засвоєнню нового знання. Наприклад, С. В. Кондратьєва та В. О. Кривошеєв [3, с. 184-186] досліджували професійну рефлексію у процесі педагогічного спілкування, розрізняючи два типи рефлексії - комунікативну та особистісну.

Викладення основного матеріалу. Рефлексивна підготовка майбутніх соціальних педагогів у закладі вищої школи припускала таку їі організацію, що сприяла формуванню високого (творчого) та середнього (достатнього) рівнів знань, умінь та навичок в галузі професійної рефлексії. ÏÏ загальними компонентами $\epsilon$ : система знань щодо професійної рефлексії майбутніх соціальних педагогів, що розвиває рефлексивне мислення та система умінь та навичок, що формується рефлексивною діяльністю. Означена система є практико-орієнтованою, тобто, містить результати досліджень щодо проблеми рефлексії та професійної рефлексії в межах філософської, психологічної та педагогічної наукової літератури; професійної рефлексії соціальних педагогів в межах діяльності та майбутніх соціальних педагогів в межах професійної підготовки у закладі вищої школи (теорія професійної рефлексії); практичний матеріал (завдання, вправи, прийоми), що формують професійну рефлексію майбутніх соціальних педагогів у закладі вищої школи (методика професійної рефлексіі).

Процес формування професійної рефлексії майбутніх соціальних педагогів 
у закладі вищої школи є частиною освітнього процесу, як підсистема він має якості цілого й тому має свою мету, компоненти, певну структуру, механізм функціонування, кінцевий результат, зв’язок з цілісним педагогічним процесом.

Для забезпечення сталого формування професійної рефлексії майбутніх соціальних педагогів доцільно використовувати технологізацію, оскільки пряме експериментування небезпечне для майбутньої діяльності фахівців соціальної сфери.

Проаналізуємо розроблену нами технологію формування професійної рефлексії майбутніх соціальних педагогів у закладі вищої школи більш докладно (рис. 1).

Під технологією формування професійної рефлексії майбутніх соціальних педагогів у закладі вищої школи ми розуміємо цілісний педагогічний процес, у якому сукупність форм, методів, засобів навчання спрямована на набуття майбутніми соціальними педагогами певних знань, умінь та навичок, а також на розвиток особистостей студентів як майбутніх практиків професійної діяльності із відповідними компетентностями та компетенціями.

Зазначимо, що технологія має особливості структури (елементи та етапи процесу формування), послідовний зв'язок цих елементів та особливості конструювання змісту формування професійної рефлексії майбутніх соціальних педагогів у закладі вищої школи. Розроблена технологія розглядається як сукупність закономірних, функціонально пов'язаних компонентів, що становлять певну цілісну систему. Виділення компонентів у технології дозволило розбити іiі на блоки (цільовиц̆, функціональний, змістовий, організаційний, результативний), які забезпечили можливість більш чітко уявити цілеспрямований процес формування професійної рефлексії майбутніх соціальних педагогів у закладі вищої освіти.

Цільовий блок. Метою освітнього процесу є забезпечення досягнення середнього (достатнього) та високого (творчого) рівнів сформованості професійної рефлексії майбутніх соціальних педагогів. Іїі реалізація і виконання полягають у таких завданнях: засвоїти теорію, ознайомити 3 основними 


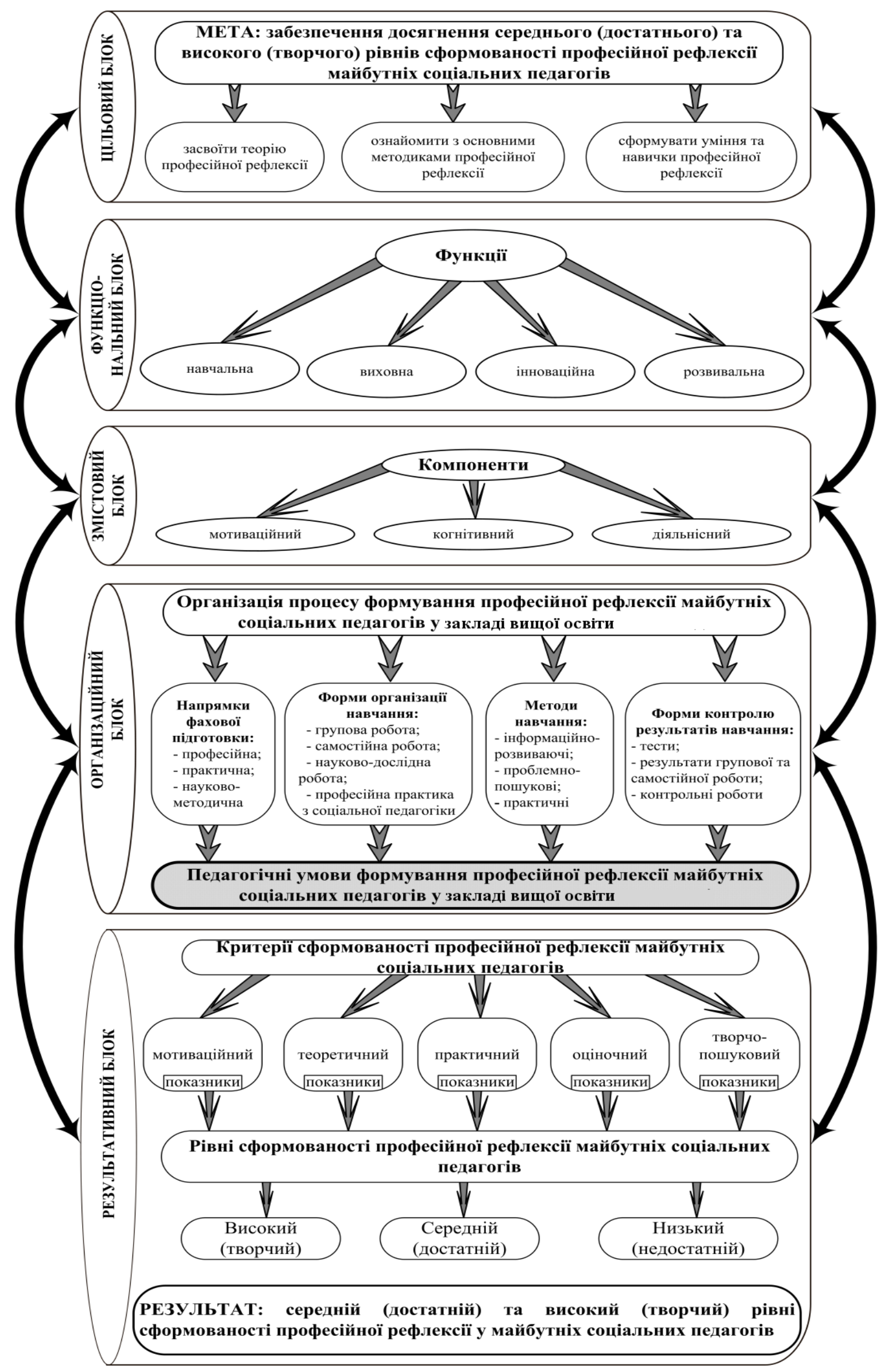

Рис. 1. Технологія формування професійної рефлексії майбутніх соціальних педагогів у закладі вищої освіти. 
методиками, сформувати уміння та навички професійної рефлексії у майбутніх соціальних педагогів.

Функціональний блок дозволяє виділити функції процесу формування професійної рефлексії майбутніх соціальних педагогів у закладі вищої школи: навчальну - формування у майбутніх соціальних педагогів системи знань про професійну рефлексію та можливості iї використання у практичній діяльності; виховну формування професійних установок та принципів, стандартів професійної поведінки; інноваційну - формування у свідомості майбутніх соціальних педагогів здатності до вирішення професійних завдань, сприяння розвитку таких якостей, як професійна мобільність і можливість адаптації до нових умов, що змінюються професійною діяльністю; розвивальна - сприяння формуванню майбутніх соціальних педагогів як особистостей та підготовка їх до самостійної професійної діяльності, самореалізації. Ефективне функціонування розробленої технології не можливе без формування у майбутніх соціальних педагогів знань, умінь і навичок професійної рефлексії; формування професійної спрямованості особистостей майбутніх соціальних педагогів; використання спецкурсу, побудованого на основі виявлення i встановлення міждисциплінарних зв’язків між загальноосвітніми та спеціальними навчальними дисциплінами.

Змістовий блок. У відповідності до мети та завдань, процес формування професійної рефлексії майбутніх соціальних педагогів у закладі вищої освіти розглядається як специфічний вид освітньої діяльності, спрямований на майбутніх соціальних педагогів 3 метою розвитку та формування їх особистостей як професіоналів. Дану діяльність визначають мотиваційний, когнітивний та діяльнісний компоненти.

Мотиваційний компонент покликаний формувати у майбутніх соціальних педагогів мотивації до професійної діяльності, розуміння сенсу цієї діяльності і свого місця в ній. Когнітивний компонент спрямований на формування у майбутніх соціальних педагогів професійних цінностей та ідеалів. Діяльнісний компонент вимагає у майбутніх соціальних педагогів конкретної дії, вчинку, поведінкового акту, застосування соціальної і професійної норми, вироблення професійної звички. 
Наступний блок технології - організаційний, в якому ми виділяємо процесуальний аспект формування професійної рефлексії майбутніх соціальних педагогів у закладі вищої освіти.

Формування професійної рефлексії майбутніх соціальних педагогів у закладі вищої освіти здійснюється під впливом усіх компонентів освітнього процесу як єдиного цілого. Цей блок представлений: напрямками фахової підготовки (професійна, практична, науково-методична); формами організащії навчання (групова робота, самостійна робота, науково-дослідна робота, професійна практика 3 соціальної педагогіки); методами навчання (інформаційно-розвиваючі, проблемно-пошукові, практичні); формами контролю результатів навчання (тести, результати групової та самостійної роботи, контрольні роботи).

Впровадження технології формування професійної рефлексії майбутніх соціальних педагогів у закладі вищої освіти неможливо без врахування педагогічних умов іiі реалізації. За суттю вони є своєрідним «стрижнем», що дозволяє їй функціонувати та бути дієвою. До педагогічних умов дієвості технології формування професійної рефлексії майбутніх соціальних педагогів у закладі вищої освіти ми відносимо: базові (системний, безперервний, контрольований вплив на процес формування професійної рефлексії майбутніх соціальних педагогів у закладі вищої освіти; навчальні умови закладу вищої освіти (технологічні, психологічні, навчальнометодичні, побутові, часові), процесуальні (орієнтація рефлексивної підготовки майбутніх соціальних педагогів у закладі вищої освіти на специфіку професійної діяльності, постійний контакт 3 організаціями, які надають послуги 3 соціальної педагогіки, створення рефлексивного середовища та активізація суб'єкт-суб'єктних взаємовідносин між науково-педагогічними працівниками та постійний контакт 3 організаціями, які надають послуги з соціальної педагогіки, створення рефлексивного середовища та активізація суб'єкт-суб'єктних взаємовідносин між науковопедагогічними працівниками та майбутніми соціальними педагогами у закладі вищої освіти, вдосконалення робочих навчальних програм 3 дисциплін професійного спрямування майбутніх соціальних педагогів у закладі вищої освіти) та формувальні (розуміння майбутніми соціальними педагогами актуальності та важливості формування професійної рефлексії у закладі вищої освіти, усвідомлений вибір майбутніми соціальними педагогами спеціальності «Соціальна педагогіка», 
формування стійкої мотивації щодо актуальності та важливості формування професійної рефлексії у закладі вищої освіти, навчально-методичне забезпечення цього процесу).

Напрямки фахової підготовки, форми організації навчання, методи навчання та форми контролю результатів навчання підпорядковуються педагогічним умовам формування професійної рефлексії майбутніх соціальних педагогів у закладі вищої освіти.

Результативний блок. Представлений критеріями та показниками рівнів сформованості професійної рефлексії майбутніх соціальних педагогів. Результатом ефективності технології формування професійної рефлексії майбутніх соціальних педагогів у закладі вищої школи є досягнення середнього (достатнього) та високого (творчого) рівнів сформованості професійної рефлексії у майбутніх соціальних педагогів.

Структурні блоки запропонованої технології $є$ взаємозв’язаними, тому досягнення мети неможливо без їх врахування. Відтак, ми пропонуємо здійснювати формування професійної рефлексії майбутніх соціальних педагогів у закладі вищої освіти на основі технології, що складається собою певну цілісну систему і дозволяє забезпечити можливість більш чіткого уявлення цілеспрямованого процесу формування професійної рефлексії майбутніх соціальних педагогів.

Впровадження технології формування професійної рефлексії майбутніх соціальних педагогів у закладі вищої освіти неможливо без врахування педагогічних умов іiі реалізації. Не дивлячись на те, що вони виступали у складі організаційного блоку обгрунтованої та розробленої технології, за суттю вони $є$ своєрідним «стрижнем», що дозволив їй функціонувати та бути дієвою. Для того, щоб впровадження технології було ефективним, необхідним є більш чітке їх розуміння та врахування при організації процесу формування професійної рефлексії у закладі вищої освіти.

Висновки. Формування професійної рефлексії майбутніх соціальних педагогів у закладі вищої освіти є успішним при наявності відповідних педагогічних умов. При чому, необхідно виявити, проаналізувати та узагальнити у системному вигляді ті педагогічні умови, які ефективно впливають на процес та професійне становлення майбутніх соціальних педагогів. Чим краще визначені та обгрунтовані педагогічні 
умови, тим більш ефективні результати досягаються. Принципові особливості означеного процесу проявляються у неможливості примусити майбутніх соціальних педагогів опанувати професійною рефлексією, способами та прийомами рефлексивної діяльності, до пошуку відповідної інформації щодо рефлексії взагалі та професійної рефлексії, зокрема. Прийнятними залишаються опосередковано-стимулюючі засоби впливу на майбутніх соціальних педагогів, що припускають активізацію їх як суб’ єктів особистісного та професійного становлення.

Таким чином, від того, у яких педагогічних умовах буде здійснюватися професійна підготовка майбутніх соціальних педагогів у закладі вищої освіти, залежить ефективність технології формування професійної рефлексії.

\section{References}

1. Velinskij M. Ya., Obrozcov P. I., Uman A. I. Tekhnologii professional'noorientirovannogo obucheniya $v$ vysshej shkole [Technology of professionally oriented education in higher education]: ucheb. posobie. Moskva: Ped. o-vo Rossii, 2004. 189 p.

2. Ziaziun I. Profesiina osvita : pedahohika i psykholohiia [Professional education: pedagogy and psychology] / za red. I. Ziaziuna, N. Nychkalo. Kyiv: Vyscha shkola, 2003. $568 \mathrm{p}$.

3. Kondrat'eva S. V., Krivosheev V. A. Pedagogicheskaya refleksiya nachinayushchih uchitelej [Pedagogical reflection of novice teachers] // Tezisy dokl. k VII syezdu obshchestva psihologov SSSR. Moskva: 1989. P. 184-186.

4. Monahov V. M. Tekhnologicheskie osnovy proektirovaniya i konstruirovaniya pedagogicheskogo processa [Theoretical foundations of the design and construction of the pedagogical process]. Moskva: 1996. $225 \mathrm{p}$.

5. Osvitni tekhnologhiji [Educational technologies]: navch.-metod. posibnyk / O. M. Pekhota ta in. Kyiv: A. S. K., 2002. 255 p.

6. Pet'ko L. V. Filosofs'ko-lingvistychni idei' rozuminnja mizhljuds'koi' komunikacii' $u$ social'nomu seredovyshi [Philosophical and linguistic ideas of interpersonality communication in professional sphere]. Naukovi zapysky. Ostrog: Vyd-vo «Ostroz'ka akademija», 2015. Serija «Filologichna». Vol. 53. PP. 353-356.

7. Petko L.V. Vyklyky XXI stolittia dlia osvitnoho prostoru Ukrainy. Naukovi pratsi ChNU: nauk. zhurnal [The challenges of educational space in the 21 - $^{\text {st }}$ century]. Mykolaiv: Vvo ChNU imeni Petra Mohyly, 2017. Vol. 303. Issue 291. P. 10-14.

8. Pet'ko L. V. Stymuljuvannja gotovnosti majbutnih social'nyh pedagogiv do vyhovnoi' roboty u procesi vyvchennja inozemnoi' movy u VNZ (na prykladi kinofil'mu "Zvuky muzyky» ("The Sound of Music»), SShA, rezh. Uajz, 1965 r.) [Stimulation of readiness of the future social teachers in a higher education institution for educational work in the process of foreign language learning (on the example of the movie "The Sound of Music», USA, Director R. Wise, 1965)]. Aktual'ni problemy navchannja ta vyhovannja 
ljudej v integrovanomu seredovyshhi: zb. nauk. prac' No 9 (11). Kyiv: Universytet «Ukrai'na». 2012. PP. 84-95.

9. Plakhotnik O. V., Vasyljjeva-Khalatnykova M. O. Profesijna refleksija $u$ dijaljnosti socialjnogho pedaghogha [The professional reflexion in the work of social teacher]: navchaljno-metodychnyj pos. Kyiv, 2013. 248 p.

10. Chernukha N.M. Formyrovanye sotsyalnoi aktyvnosty studentov v sovremennom intehratsyonnom obrazovatelnom prostranstve [Formation social activity of students in studentov in modern educational space]. Osvitnia polityka derzhavy. Kyiv, 2014. P.137-140

11. Chernukha N.M., Aslanov H. Sotsialni komunikatsii v interkulturnomu prostori: vidpovid na vyklyky sohodennia [Social communications in intercultural space: response to challenges]. Innovative processes in education: Collective monograph. - AMEET Sp. z o.o., Lodz, Poland, 2017.

12. Kulyk Olena. Reflection as a component to professional becoming tomorrow's specialist in the higher education system. Topical questions of contemporary science: Collection of scientific articles. Aspekt Publishing of Budget Printing Center, Taunton, MA 02780, United States of America, 2017. P. 441-447.

13. Shkolna Maria. Pedagogical conditions for upbringing social maturity of students' agricultural colleges. Intellectual Archive. Toronto: Shiny Word.Corp. (Canada). 2017. September/October. Vol. 6. No. 5. PP. 79-85.

\section{Translation of the Title, Abstract and References to the Author's Language}

\section{УДК 378.012.11.234}

Чернуха Н. М., Васильєва-Халатникова М. О., Токарук Л. С. Технологія формування професійної рефлексії майбутніх соціальних педагогів у закладі вищої школи.

У статті подано технологію формування професійної рефлексії майбутніх соціальних педагогів у закладі вищої школи. Розроблена технологія розглядається як сукупність закономірних, функціонально пов'язаних компонентів, що становлять певну цілісну систему. Виділення компонентів у технології дозволило розбити ії на блоки (цільовий, функціональний, змістовий, організаційний, результативний), які забезпечують можливість більш чітко уявляти цілеспрямований процес формування професійної рефлексії майбутніх соціальних педагогів у закладі вищої школи. Формування професійної рефлексії майбутніх соціальних педагогів у закладі вищої школи буде успішним при наявності відповідних педагогічних умов. Запропоновано педагогічні умови, які ефективно впливають на процес та професійне становлення майбутніх соціальних педагогів.

Ключові слова: технологія, професійна рефлексія, соціальний педагог, заклад вищої школи, педагогічні умови.

\section{תimepamypa}

1. Виленский М. Я., Образцов П. И., Уман А. И. Технологии профессиональноориентированного обучения в высшей школе : уч. - Москва: Педагогическое общество России, 2005. - 192 с.

2. Зязюн І. А. Педагогіка добра: ідеї і реалії: наук.-метод. посібник. - Київ: МАУП, 2003. - 312 с. 
3. Кондратьєва С. В., Кривошеєв В. О. Педагогічна рефлексія майбутніх // Тези доп. до VII с’їзду спільноти психологів. - Москва: 1989. - С. 184-186.

4. Монахов В. М. Технологічні основи проектування та конструювання педагогічного процесу. - Москва: 1996. - 225 с.

5. Освітні технології: навч.-метод. посібник / О. М. Пехота [та ін.]. - Київ: А. С. K., 2002. - 255 c.

6. Петько Л. В. Філософсько-лінгвістичні ідеї розуміння міжлюдської комунікації у соціальному середовищі. Наукові записки Національного університету «Острозька академія». Серія «Філологічна» : зб. наук. праць / укл. І.В.Ковальчук, Л.М.Коцюк, С.М.Новоселецька. Острог : Вид-во Національного ун-ту «Острозька академія», 2015. Вип. 53. С. 309-312.

7. Петько Л. В. Виклики ХХІ століття для освітнього простору України. Наукові nраці [Чорноморського держ. ун-ту імені Петра Могили комплексу "КиєвоМогилянська академія"]. Серія : Педагогіка : наук. журн. / Чорном. держ. ун-т імені Петра Могили; ред. кол. : О. П. Мещанінов (голова) [та ін.]. Миколаїв : Вид-во ЧНУ імені Петра Могили, 2017. Т. 303. Вип. 291. С. 10-14.

8. Петько Л.В. Стимулювання готовності майбутніх соціальних педагогів до виховної роботи у процесі вивчення іноземної мови у ВНЗ (на прикладі кінофільму «Звуки музики» («The Sound of Music»), США, реж. Уайз, 1965 р.). Актуальні проблеми навчання та виховання людей в інтегрованому середовищі: зб. наук. праць № 9 (11). Київ: Університет «Україна». 2012. С. 84-95.

9. Плахотнік О. В., Васильєва-Халатникова М. О. Професійна рефлексія у діяльності соціального педагога: навч.-метод. посібник. - Київ, 2013. - 248 с.

10. Чернуха Н.M. Формирование социальной активности студентов в современном интеграционном образовательном пространстве. Освітня політика держави : філософія, методологія, практика. Тематичний випуск. Київ, 2014. С. 137140.

11. Чернуха Н.М., Асланов Г. Соціальні комунікації в інтеркультурному просторі: відповідь на виклики сьогодення. Innovative processes in education: Collective monograph. - AMEET Sp. z o.o., Lodz, Poland, 2017.

12. Kulyk Olena. Reflection as a component to professional becoming tomorrow's specialist in the higher education system. Topical questions of contemporary science: Collection of scientific articles. Aspekt Publishing of Budget Printing Center, Taunton, MA 02780, United States of America, 2017. P. 441-447.

13. Shkolna Maria. Pedagogical conditions for upbringing social maturity of students' agricultural colleges. Intellectual Archive. Toronto: Shiny Word.Corp. (Canada). 2017. September/October. Vol. 6. No. 5. PP. 79-85. 